\title{
Agriculture and food animals as a source of antimicrobial-resistant bacteria
}

This article was published in the following Dove Press journal:

Infection and Drug Resistance

I April 2015

Number of times this article has been viewed

\author{
Vangelis Economou' \\ Panagiota Gousia ${ }^{2}$ \\ 'Department of Hygiene and \\ Technology of Food of Animal \\ Origin, School of Veterinary \\ Medicine, Faculty of Health Sciences, \\ Aristotle University of Thessaloniki, \\ Thessaloniki, Greece; ${ }^{2}$ Food-Water \\ Microbiology Unit, Department of \\ Microbiology, Faculty of Medicine, \\ School of Health Sciences, University \\ of Ioannina, loannina, Greece
}

\begin{abstract}
One of the major breakthroughs in the history of medicine is undoubtedly the discovery of antibiotics. Their use in animal husbandry and veterinary medicine has resulted in healthier and more productive farm animals, ensuring the welfare and health of both animals and humans. Unfortunately, from the first use of penicillin, the resistance countdown started to tick. Nowadays, the infections caused by antibiotic-resistant bacteria are increasing, and resistance to antibiotics is probably the major public health problem. Antibiotic use in farm animals has been criticized for contributing to the emergence of resistance. The use and misuse of antibiotics in farm animal settings as growth promoters or as nonspecific means of infection prevention and treatment has boosted antibiotic consumption and resistance among bacteria in the animal habitat. This reservoir of resistance can be transmitted directly or indirectly to humans through food consumption and direct or indirect contact. Resistant bacteria can cause serious health effects directly or via the transmission of the antibiotic resistance traits to pathogens, causing illnesses that are difficult to treat and that therefore have higher morbidity and mortality rates. In addition, the selection and proliferation of antibiotic-resistant strains can be disseminated to the environment via animal waste, enhancing the resistance reservoir that exists in the environmental microbiome. In this review, an effort is made to highlight the various factors that contribute to the emergence of antibiotic resistance in farm animals and to provide some insights into possible solutions to this major health issue.
\end{abstract}

Keywords: antimicrobial resistance, farm animals, food safety, foodborne pathogens, alternatives to antibiotics

\section{Introduction}

Antimicrobials have been used in human and veterinary medicine for more than 60 years. Almost simultaneously, the use of antimicrobials has been applied in agriculture to prevent, control, and treat infections and to improve growth and feed efficiency. ${ }^{1,2}$ The importance of the positive effects of the use of antibiotics in agriculture is summarized in a World Health Organization reference, in which it is stated that "antimicrobials are vital medicines for the treatment of bacterial infections in both humans and animals. Antimicrobials have also proved to be important for sustainable livestock production and for the control of animal infections that could be passed on to humans." Still, the overuse or misuse of antimicrobials has been blamed for the selection of resistant isolates, giving birth to the term antimicrobial resistance. ${ }^{4}$ According to the World Health Organization, the following definition has been given: "Antimicrobial resistance ... is resistance of a microorganism to an antimicrobial drug that was originally effective for treatment of infections caused by it." Still, the link
Correspondence: Vangelis Economou Laboratory of Hygiene of Food of Animal Origin, School of Veterinary Medicine, Faculty of Health Sciences, Aristotle University of Thessaloniki,

54I24 Thessaloniki, Greece

Tel +30 23I0 999875

Fax +3023I0 999833

Email boikonom@vet.auth.gr 
between use and overuse of antibiotics and resistance is not easy to follow, as antimicrobial resistance is a very complex and nonvictimless phenomenon affecting both human and animal health. ${ }^{6}$

The rise of antimicrobial resistance after the first use of antibiotics should have been expected. ${ }^{2}$ Bacteria are quite adaptive organisms that have survived multiple environmental stresses during their existence on the planet. Still, the emergence of antibiotic-resistant bacteria occurred quite shortly after their first use. In 1948, Staphylococcus aureus strains isolated from patients in British hospitals were found to be resistant to penicillin, ${ }^{7}$ and in the same year, soon after the drug's first use, resistance to streptomycin was observed in Mycobacterium tuberculosis isolates. ${ }^{8}$ In the 1950s, antimicrobial resistance was confirmed in other pathogenic bacteria, such as Escherichia coli, Shigella spp., and Salmonella enterica, ${ }^{9-11}$ whereas in the $1960 \mathrm{~s}$, antibiotic-resistant bacteria such as extended spectrum $\beta$-lactamases (ESBLs) producing Enterobacteriaceae, vancomycin-resistant Enterococcus spp. (VRE), methicillin-resistant S. aureus (MRSA), and multidrug-resistant Acinetobacter baumannii were encountered. ${ }^{11-13}$ Concerning outbreaks resulting from resistant bacteria from animals, data are limited, mainly because of the difficulty in discriminating the origin of these bacteria. Therefore, outbreak data traced back to animal can be safely attributed when the vehicle of transmission is food of animal origin.

\section{Antimicrobial use in agriculture, animal husbandry, and aquaculture}

Antimicrobials have been used in animals for treatment of diseases, for prevention and control of diseases, and also as growth promoters. ${ }^{13}$ Therapeutic use of antimicrobials in animal husbandry should be accompanied ideally by an antimicrobial susceptibility test. According to the determination of the results, the drug's attributions (pharmacodynamics, pharmacokinetics, toxicity, and tissue distribution), the age, the immune status of the animal, the cost of the drug, and the approval of the species, the appropriate drug is chosen. ${ }^{14}$ However, in the case of infectious diseases, usually the whole flock is treated to prevent the dissemination of illness in the flock, despite the exhibition of clinical symptoms in a few animals. This is known as metaphylaxis, in which usually high doses of antibiotics are given for a short period. Still, the red line between use of antibiotics for treatment or prevention is not clear. ${ }^{15,16}$ In contrast, the use of antimicrobials for prevention (also known as prophylaxis) refers to the administration of antimicrobials in the feed or the drinking water in low doses for a longer period of time, usually for several weeks. During this period, the animals are not showing clinical signs, but the risk for infection exists. ${ }^{16}$

The benefits of use of antimicrobials as antimicrobial growth promoters were first reported by Stokstad and Jukes, ${ }^{17}$ when they noticed that small subtherapeutic doses of penicillin and tetracycline could enhance weight gain. Antimicrobial growth promoters are no longer permitted in the European Union, but they are still used in North America and other countries. ${ }^{16}$ Subtherapeutic levels of antibiotics promote growth, but still the mechanism of this action remains unclear. Among the hypotheses tested are the stimulation of intestinal synthesis of vitamins, the reduction of total bacteria in the intestinal tract and the subsequent reduction in nutrient competition between microorganisms and host, the inhibition of harmful bacteria, the reduced immune stimulation, and the modification of rumen microbial metabolism. ${ }^{18,19}$ These subtherapeutic doses are not sufficient to destroy the target bacteria, allowing the more resistant of them to survive. ${ }^{16}$ A few years ago, the US Food and Drug Administration issued draft guidance to animal farmers, veterinarians, and drug makers, which represents a step toward stopping antibiotic use for growth promotion. ${ }^{20}$ In the European Union, antimicrobial growth promoters were withdrawn in 2006 , although ionophores continue to be administered in feed. ${ }^{21}$

The use of veterinary antimicrobial agents in foodproducing animals in countries of European Union and the United States of America is presented in Tables 1 and 2, as reported by the European Medicines Agency, ${ }^{22-25}$ and the US Food and Drug Administration. ${ }^{26-29}$ According to these data, the consumption of antibiotics for animal use has been augmented by $\sim 4 \%$ in the European Union, whereas in the United States, it follows an ascending trend, despite the call for limiting antimicrobial use in livestock.

In cattle, antimicrobials such as amoxicillin, penicillin, erythromycin, quinolones, gentamicin, novobiocin, tylosin, tilmicosin, and tetracycline are extensively used. In meatproducing animals, antibiotics are mainly used for the treatment and prevention of bovine pneumonia, diarrhea, and shipping fever, which are the most common problems. ${ }^{29}$ For the treatment of pneumonia, oxytetracyclines and spectinomycin are the firstchoice antibiotics, with florfenicol and macrolides (particularly tilmicosin) considered as the second choice, with second-, third-, and fourth-generation cephalosporins being the last choice. ${ }^{30}$ Still, antibiotics are administered at least once via feed for various reasons, such as liver abscesses, increased growth, and respiratory diseases. ${ }^{31}$ The use of narrow-spectrum antimicrobials is favored in cases of clinical mastitis, with first-choice antimicrobials being the $\beta$-lactam antimicrobials used when 
Table I Sales (tons of active ingredient) of veterinary antimicrobial agents applicable mainly for food-producing animals, including horses, on average per European Union member state between 2005 and $2012^{22-25}$

\begin{tabular}{|c|c|c|c|c|c|c|c|}
\hline Antimicrobial class & 2005 & 2006 & 2007 & 2008 & 2009 & 2011 & 2012 \\
\hline Tetracyclines & 148.6 & 143.7 & 157.4 & 134.4 & 119.0 & 123.2 & 113.2 \\
\hline Amphenicols & 1.0 & I.I & 1.3 & I.I & I.I & 2.0 & 2.2 \\
\hline Penicillins & 34.7 & 35.7 & 35.0 & 35.7 & 37.1 & 77.9 & 68.5 \\
\hline Cephalosporins (total) & 1.7 & 1.9 & 1.9 & 1.9 & 1.7 & 0.6 & 0.8 \\
\hline First- and second-generation cephalosporins & 1.3 & 1.3 & 1.3 & 1.1 & 1.3 & 0.3 & 0.3 \\
\hline Third- and fourth-generation cephalosporins & 0.4 & 0.4 & 0.4 & 0.4 & 0.4 & 0.6 & 0.5 \\
\hline Sulfonamides and trimethoprim (total) & 53.7 & 53.3 & 56.6 & 51.6 & 48.7 & 72.6 & 36.7 \\
\hline Sulfonamides & 46.0 & 45.7 & 48.9 & 44.6 & 42.0 & 36.3 & 31.8 \\
\hline Trimethoprim & 7.7 & 7.6 & 7.7 & 7.0 & 6.7 & 5.5 & 5.0 \\
\hline Macrolides & 21.3 & 24.0 & 24.4 & 23.3 & 21.0 & 27.2 & 24.5 \\
\hline Lincosamides & 2.3 & 2.0 & 2.0 & 1.7 & 1.7 & 9.7 & 9.0 \\
\hline Aminoglycosides & 14.6 & 14.4 & 13.9 & 13.0 & 13.0 & 6.6 & 11.2 \\
\hline Quinolones (total) & 4.6 & 4.6 & 4.4 & 4.0 & 3.3 & 10.9 & 7.2 \\
\hline Fluoroquinolones & 0.9 & 1.0 & 1.0 & 0.9 & 1.0 & 5.5 & 5.2 \\
\hline Other quinolones & 3.7 & 3.6 & 3.4 & 2.9 & 2.1 & 2.2 & 1.9 \\
\hline Polymyxins & 10.0 & 10.1 & 11.3 & 10.1 & 10.3 & 22.4 & 21.0 \\
\hline Pleuromutilins & 2.7 & 2.6 & 3.0 & 3.6 & 3.6 & 8.5 & 8.8 \\
\hline Others* & 0.4 & 0.4 & 0.4 & 0.6 & 0.7 & 9.0 & 3.9 \\
\hline Total & 295.6 & 293.7 & 311.6 & 280.9 & 261.1 & 336.8 & 307.0 \\
\hline
\end{tabular}

Notes: *Others include bacitracin, paromycin, spectinomycin, polymyxins, and amphenicols. Data were derived for cumulative reports involving seven European Union member states in 2005-2009, 25 in 201 I, and 26 in 2012. Data from the European Medicines Agency. ${ }^{22-25}$

treating mastitis resulting from streptococci, or penicillin when treating mastitis caused by staphylococci. ${ }^{30,32}$ In certain cases, the use of antibiotics intramammary in the nonlactating period is given to the whole herd to prevent infectious mastitis. ${ }^{32}$

In pigs, the current trends in husbandry require animal segregation in groups according to age, where pigs are of similar size and weight, and therefore the antimicrobials

Table 2 Antimicrobial drugs approved for use in food-producing animals actively marketed in the United States between 2009 and 2012 (tons of active ingredient)

\begin{tabular}{lllll}
\hline Drug class & $\mathbf{2 0 0 9}$ & $\mathbf{2 0 1 0}$ & $\mathbf{2 0 I I}$ & $\mathbf{2 0 1 2}$ \\
\hline Aminoglycosides & 223.12 & 211.79 & 214.89 & 273.53 \\
Cephalosporins & 20.14 & 24.59 & 26.61 & 27.65 \\
Lincosamides & 93.33 & 154.65 & 190.1 & 218.14 \\
Macrolides & 562.06 & 553.23 & 582.84 & 616.27 \\
Penicillins & 691.64 & 884.42 & 885.3 & 965.2 \\
Sulfonamides & 505.9 & 517.13 & 383.1 & 493.51 \\
Tetracyclines & $5,260.99$ & $5,602.28$ & $5,652.85$ & $5,954.36$ \\
lonophores & $3,739.35$ & 3,820 & $4,122.4$ & $4,573.79$ \\
Not independently & 329.39 & 281.22 & 319.99 & 344.43 \\
$\begin{array}{l}\text { reported (medically } \\
\text { important)* }\end{array}$ & & & & \\
$\begin{array}{l}\text { Not independently } \\
\text { reported (not medically }\end{array}$ & $1,161.54$ & $1,237.78$ & $1,190.94$ & $1,151.53$ \\
important) & & & & \\
Total & & & & \\
\hline Notes: & $14,618.43$ & $12,587.46$ & $13,287.1$ & $13,569.04$ \\
\hline
\end{tabular}

Notes: *Amphenicols, diaminopyrimidines, fluoroquinolones, and streptogramins; taminocoumarins, glycolipids, pleuromutilins, polypeptides, and quinoxalines. Data from the FDA Center for Veterinary Medicine. ${ }^{25-28}$

Abbreviation: FDA, US Food and Drug Administration. can be administered in groups of pigs via the oral route by addition in the feed or water. ${ }^{33,34}$ Individual therapy of pigs by injection of antimicrobials is mainly considered in pigs reared for reproduction. Use of antimicrobials for prevention is a common practice in pig farms, especially in stressful periods that predispose for infectious diseases. Such periods are the time between birth and first lactation, where the cut of the umbilical cord and tail and the trimming of the canines takes place; the ablactation period, where the environment and diet change and the castration of males and vaccinations take place; and finally the fattening period, where overcrowding, inadequate aeration, and low or high temperatures can form a quite stressful environment. ${ }^{35}$ Prophylactic use of antimicrobials is considered to be higher in the ablactation period, whereas at the end of fattening pigs, they do not receive antimicrobials so as to avoid residues detection after slaughter. For the prevention and treatment of enzootic pneumonia, large quantities of various antibiotics are used, with the most common being ceftiofur, tetracyclines, tiamulin, lincomycin, and enrofloxacin. ${ }^{29,34}$ In addition, in bacterial enteritis, especially when the etiological agent is $E$. coli or Clostridium perfringens, antibiotic treatment with penicillins, tetracyclines (chlortetracycline, oxytetracycline), quinolones (enrofloxacin), or aminoglycosides (gentamicin, neomycin) is required. Finally, in swine dysentery (Brahyspira hyodysenteriae) and ileitis (Lawsonia intracellularis), lincomycin, tiamulin, macrolides, or tetracyclines are mainly used. ${ }^{36}$ 
In poultry, antibiotics used for therapeutic reasons are usually administered through water, in contrast to growthpromoting use, where antibiotics are added in feed. ${ }^{37}$ The most commonly used antibiotics are penicillins (amoxicillin), quinolones (enrofloxacin), tetracyclines (doxycycline, oxytetracycline), macrolides (erythromycin, tylosin), aminoglycosides, the sulfonamide/trimethoprim combination, polymyxins (colistin), and other antimicrobials (tiamulin). ${ }^{13}$ In the United States, the abovementioned antibiotics are used, with the exception of fluoroquinolones. ${ }^{34}$

The antimicrobials commonly used in sheep and goats are amoxicillin, ampicillin, ceftiofur, the combination of amoxicillin/clavulanic acid, enrofloxacin, erythromycin, lincomycin, oxytetracycline, sulfonamides, penicillin G, trimethoprim and sulfonamide combination, tylosin, and tilmicosin (with the exception of goats, where subcutaneous injection of tilmicosin has been linked to death). ${ }^{38}$ Ampicillin, erythromycin, lincomycin, the trimethoprim and sulfonamide combination, and certain sulfonamides (eg, sulfathiazole) can significantly alter the microbial flora of the rumen when administered per os, and in certain cases, they can lead to death. ${ }^{38}$ Therefore, in the mature small ruminants, it is preferable to administer antimicrobials in other ways than the oral route (feed or water), with the exception of certain sulfonamides and tetracyclines, which can be absorbed efficiently by the rumen.

Concerns about the extensive use of nontherapeutic agents have arisen after the duplication of the antimicrobial use in aquaculture in the decade 1994-2004..$^{39,40}$ In aquaculture animals, several classes of antibiotics have been used. Among them are antibiotics such as sulfonamides, penicillins, quinolones, tetracyclines, and phenicols, which are listed as critically or highly important antimicrobials for human medicine. ${ }^{41,42}$ The last three antimicrobial classes are widely used in salmon farming. Quinolones, tetracyclines, and phenicols are selective for a variety of antimicrobial resistance genes that occur in transposons, plasmids, and integrons that, when mobile, can induce their dissemination. ${ }^{42-44}$

\section{Antimicrobial resistance in various bacteria of animal origin Campylobacter spp.}

Thermotolerant Campylobacter spp. are one of the leading causes of foodborne disease worldwide. Although the disease is self-limiting with low mortality, the economic and public health consequences are quite severe, especially in industrialized countries ${ }^{45}$ Campylobacter spp. isolates are reported to be resistant toward quinolones, macrolides and lincosamides, chloramphenicol, aminoglycosides, tetracycline, ampicillin and other $\beta$-lactams, cotrimoxazole, and tylosin. ${ }^{45-48}$ Concerning macrolide resistance, the occurrence of erythromycin resistance is higher in Campylobacter coli than Campylobacter jejuni $(0 \%-29 \%$ and $0 \%-20 \%$, respectively). In contrast to macrolides, resistance to quinolones has emerged during the last 20 years, coinciding with the use of fluoroquinolones (mainly enrofloxacin) in veterinary medicine. ${ }^{48}$ In the Netherlands, an increase was observed in fluoroquinolone-resistant Campylobacter spp. of poultry origin a few years after the use of fluoroquinolones in the country. ${ }^{49}$ Regarding tetracyclines, they have been proposed as an alternative to Campylobacter spp. infection. ${ }^{50}$ Still, the susceptibility of Campylobacter spp. to tetracyclines shows major geographical differences and generally follows increasing trends, as shown in Campylobacter spp. human isolates over the course of the last 20 years in Canada ${ }^{51,52}$ and from 1989 to 1999 in Mexico. ${ }^{48,53}$ Concerning aminoglycosides, resistance has been low in most countries, with resistance to gentamicin reported in less than $2 \%$ of the isolates ${ }^{54,55}$ Still, in the latest surveillance reports, up to $13.6 \%$ of the strains tested were resistant to gentamicin (as reported by Spain for 2012), ${ }^{56}$ and therefore sensitivity testing is advised. In addition, the resistance to gentamicin of Campylobacter spp. from meat from broilers in the European Union ranged from $0 \%$ to $6.3 \% .{ }^{56}$ Similarly, in the United States, resistance of C. coli to gentamicin between 2007 and 2011 increased from almost zero to $12.2 \%$ for human isolates, $1 \%$ to $18 \%$ for chicken meat isolates, and $1 \%$ to $6 \%$ for chicken at slaughter isolates, whereas for $C$. jejuni, resistance remained low. ${ }^{57}$

\section{Salmonella spp.}

Salmonella is one of the most important foodborne pathogens. The National Antimicrobial Resistance Monitoring System (a collaboration among the US Food and Drug Administration, the Centers for Disease Control and Prevention, and the US Department of Agriculture) and the European Food Safety Authority, along with the European Centre for Disease Prevention and Control in Europe, are monitoring Salmonella susceptibility in isolates from farm animals, food stuff, and humans. In the case of Salmonellae, the link between antibacterial use and antibiotic-resistant strains at the farm level and the occurrence in humans is well established. ${ }^{58,59}$ Still, the role of crops where wastewater or manure is used for fertilization of the fields remains to be elucidated.

Salmonella has exhibited multidrug resistance to various agents, including tetracyclines, sulfonamides, streptomycin, kanamycin, chloramphenicol, and some of the $\beta$-lactam 
antibiotics (penicillins and cephalosporins). ${ }^{60-62}$ It should be noted that the percentage of isolates resistant to these antibiotics has decreased or remained stable since 1996. In contrast, drugs such as amoxicillin/clavulanic acid, ceftriaxone, ceftiofur, and nalidixic acid follow an increasing trend. ${ }^{63}$ From 1998 to 2005 , the percentage of amoxicillin/clavulanic acid- and ceftiofur-resistant isolates has increased from less than $2 \%$ to more than $15 \%$, whereas ceftriaxone resistance increased from no resistance to $\sim 1 \%$. This increase in resistance in extended-spectrum cephalosporins is of utmost importance because ceftriaxone is used in severe salmonellosis in children. ${ }^{64}$ Resistance to more than one antibiotic has been noted as early as the $1960 \mathrm{~s} .{ }^{65}$ Nowadays, the most common multidrug resistance phenotype is the one conferring resistance to ampicillin, chloramphenicol, streptomycin, sulfonamides, and tetracyclines. ${ }^{63}$ It is also noteworthy that Salmonella spp. exhibit a remarkable ability to spread worldwide. One such example is the global dissemination of the MDR Salmonella Typhimurium DT104. ${ }^{66-68}$

\section{Staphylococcus spp.}

S. aureus is one of the most common human and animal pathogens. Bovine strains produce mostly beta-hemolysin, whereas human isolates have the ability to produce alphahemolysin. ${ }^{69}$ S. aureus was one of the first strains characterized as resistant to antimicrobials, with resistance to penicillins observed as early as $1948 .{ }^{70}$ Nowadays, resistance of human isolates to penicillin is recorded as up to $90 \%{ }^{71}$ Penicillin was first used in animal production in the late 1940s, mainly for the eradication or treatment of Streptococcus agalactiae in bovine mastitis. Its widespread use led to the selection of penicillin-resistant strains of $S$. aureus. Resistant pathogens have been noted in dairy milk, where according to Frey et $\mathrm{al}^{72}$ $47 \%$ of coagulase-negative staphylococci showed resistance to oxacillin. Even though MRSA has been a major cause of hospital-acquired infections for more than 3 decades, MRSA clonal complex 398 (MRSA CC398), a new variant, has emerged in livestock. ${ }^{73}$ Nasal carriage of livestock-associated MRSA CC398 among farmers and other persons in contact with animals has been widely reported. ${ }^{74}$ Although MRSA CC398 is quite common among pigs, it does not seem to have pronounced host specificity, as it has been also isolated from cattle, dogs, horses, and chickens. ${ }^{73}$

\section{Enterococcus spp.}

Enterococci are commensal bacteria colonizing the intestinal tract of mammals and birds; they are considered indicators of enteric contamination of food and can survive in unfavorable environmental conditions such as high or low temperature, $\mathrm{pH}$, and saline waters. ${ }^{75-77}$ During the most recent 2 decades, enterococci have emerged as an important cause of nosocomial and community-acquired infections, which are difficult to treat because they exhibit resistance to antibiotics. ${ }^{78,79}$ In addition, a rapid increase of VRE, isolated from livestock and related food products, has been observed, probably as a result of the widespread use or misuse of glycopeptide antimicrobials such as avoparcin in food-producing animals in countries other than the United States. ${ }^{80,81}$ Vancomycin and teicoplanin are used for the treatment of human infections in case of resistance or allergic reactions to $\beta$-lactams; however, the therapeutic action of vancomycin has been limited because of the emergence of VRE. ${ }^{82,83}$ Enterococci of foodborne origin are not identified as a direct cause of resistant enterococci in humans, but they could pose a risk in transfer of resistance determinants to human-adapted strains of the same genus or other genera, as shown for vancomycin resistance in $S$. aureus and tetracycline and erythromycin resistance in Listeria monocytogenes. ${ }^{77,80}$

\section{ESBL-producing Gram negative bacteria}

ESBLs are enzymes of Gram-negative bacteria conferring resistance against $\beta$-lactam antibiotics, such as third- or fourth-generation cephalosporins and monobactams. ESBLproducing Gram-negative bacteria have been reported in Europe and worldwide. ${ }^{41,84-86}$ Most ESBL-producing bacteria are multidrug-resistant, and the majority of them are only susceptible to carbapenems. ${ }^{21}$ Infections caused by these multidrug-resistant bacteria are associated with high morbidity, high mortality, high health care costs, and limited therapeutical options. $^{41}$

Resistance genes of the ESBL type are mostly plasmidassociated, and therefore can spread among bacteria. ${ }^{87}$ Recently, there has been an ongoing concern about the dissemination of ESBL-producing strains in healthy food animals, with many reports referring to strains from Europe, Asia, and the United States. ${ }^{70,88}$ The increasing incidence of infection with ESBL-producing $E$. coli has been observed in food animals such as cattle, broiler chickens, and pigs. ${ }^{41,87}$ This observation suggests that animals, food, and environment are potent sources of ESBL-producing bacteria. ${ }^{41}$ According to Reich et al, ${ }^{87}$ ESBL-producing enterobacteria were isolated from $88.6 \%$ of carcasses and $72.5 \%$ of ceca at slaughter. Overdevest et $\mathrm{al}^{89}$ found a high prevalence of ESBL-coding genes in retail chicken meat (79.8\%), with genetic analysis showing that the predominant ESBL-coding genes in chicken meat and human rectal swab specimens 
were identical. Other data show clearly that antibiotic administration to chickens leads to more ESBL-producing bacteria in chicken meat. ${ }^{90}$

\section{Modes of spread to humans from farm animals and food}

The possible transport routes between animals and humans are numerous. Still, the most probable ways of interaction are summarized in transmission through the food chain; ${ }^{91}$ through direct or indirect contact with people working in close contact with animals, such as farmers and animal health workers; ${ }^{92}$ and through manure contaminated environments and aquaculture..$^{93,94}$ In particular, the role of the environment is extremely important, as it can serve as the reservoir of antibiotic-resistance genes..$^{95,96}$

Although the immediate risk from antibiotic-resistant foodborne pathogens is easier to comprehend, perhaps the most perilous situation is the transfer of antimicrobial resistance characteristics through the genetic pool contained in bacteria, bacteriophages, or DNA fragments. According to Rossi et al, ${ }^{97}$ horizontal gene transfer, the mechanism by which most bacteria could transfer antibiotic resistance genes, may occur in all matrices. Still, it is more probable in food categories containing high numbers of microbial cells (fermented, minimally processed, or raw foods). ${ }^{97}$ The cohabitation of these factors with pathogenic bacteria in various environments, and especially in the human gut, could result in the appearance of resistant strains. This has been shown in vitro by Toomey et al, ${ }^{98}$ who have demonstrated the transfer of erythromycin resistance genes from lactic acid bacteria to L. monocytogenes. In addition, Doucet-Populaire et $\mathrm{al}^{99}$ report the transfer of tetracycline and erythromycin resistance genes from Enterococcus faecalis to L. monocytogenes strains in vitro and in the gastrointestinal tract of mice. Ampicillin resistance has been transferred from Salmonella typhimurium to E. coli in milk and ground beef. ${ }^{100}$ Rizzotti et al ${ }^{101}$ have succeeded in transferring tetracycline resistance genes from E. faecalis to Listeria innocua in meat.

In addition, the transfer of resistance is well documented in bacteria of the same species in the human digestive tract. In $E$. coli, genes encoding ESBLs could be harbored in mobile genetic elements and could therefore be transmitted to other E. coli strains, as demonstrated in vitro. ${ }^{102}$ In addition, Leverstein-van Hall et al $^{103}$ provide indirect evidence of transfer of resistance to $\beta$-lactamic antibiotics through the food chain. They report that $54 \%$ of the $E$. coli of human origin carried ESBL genes that were genetically identical to those of poultry origin. Therefore, bacteria that contain antimicrobial resistance genes can be an indirect public health hazard, regardless of their pathogenicity, as the available genetic pool of resistance is increased.

\section{Health risks to humans}

The higher burden on human health of antibiotic-resistant foodborne pathogens versus antibiotic-sensitive ones has been well documented. Concerning Salmonella spp. and Campylobacter spp., the rise of antimicrobial resistance has resulted in an increased number of hospitalizations and increased morbidity and mortality. Doyle and Erickson, ${ }^{104}$ in a review of emerging pathogens from meat, report selected outbreaks in which increased severity was exhibited, coinciding with the etiological agents being antibiotic-resistant bacteria.

In general, the increased severity of infection resulting from antibiotic-resistant bacteria could be summarized as follows:

1. Delay or failure of treatment. The administration of antibiotics in patients, especially in severe cases, is often given empirically before the results of the antibiogram. Therefore, antibiotic therapy fails. In some cases, the deterioration of the patient in the relapsed time is fatal.

2. Limited choice of antimicrobials. The available antimicrobials are limited because of the emergence of antibiotic-resistant pathogens. In addition, the increased use of the effective antimicrobials increases the possibility of the appearance of new resistant strains.

3. Selection of suppressed resistant pathogenic strains when antibiotic therapy is administered for treatment of other bacterial diseases.

4. Coexistence ${ }^{105,106}$ and possibly increased regulation ${ }^{107}$ of pathogenicity genes with resistance genes as a result of selection. The result is the emergence of highly pathogenic strains that are resistant to antibiotics. As an example, in S. typhimurium, DT104 multiple antibiotic resistance is expressed by a gene cluster (SGI1), in which genes encoding virulence proteins are contained. ${ }^{104}$

The human health risks associated with consumption of raw or unpasteurized milk and milk products are well established and have been previously reviewed by Oliver et al. ${ }^{108}$ In general, the precise quantification of the total effect of antibiotic resistance in terms of morbidity and mortality is quite difficult, as it is a problem added to the initial infection. ${ }^{109}$ Still, the severity of the infection in terms of the total duration and seriousness is expected to be more profound. It has been documented that the augmenting 
appearance of antibiotic-resistant bacteria has led to an increase in foodborne illnesses. ${ }^{110}$ More specifically, the augmenting percentages of antibiotic-resistant Salmonella spp. and Campylobacter spp. have been linked to increase in hospitalizations, risk for invasive infections, and mortality. ${ }^{111}$ According to European Centre for Disease Prevention and Control/European Medicines Agency, ${ }^{112}$ the burden of antibiotic-resistant bacteria that caused bloodstream infections in the European Union, Iceland, and Norway in 2007 was estimated to add 386,100 cases, 25,100 deaths, and 2,536,000 hospitalization days. Although the number of cases caused by Gram-positive antibiotic-resistant bacteria (namely, methicillin-resistant staphylococci and vancomycin-resistant enterococci) was comparable to that of Gram-negative bacteria, almost two-thirds of deaths were attributed to Gram negative antibiotic resistant bacteria. ${ }^{112}$

\section{Alternatives to nontherapeutic agents in agriculture and aquaculture}

In an effort to estimate the increased health care economic burden of antibiotic-resistant bacteria, the National Academy of Sciences estimated that the annual cost ranged between $\$ 4$ and $\$ 5$ billion. Still, the loss of work days and productivity was not included. ${ }^{113}$ In 2009, the annual cost was estimated at between \$16.6 and \$26 billion by the Cook County Hospital and the Alliance for Prudent Use of Antibiotics, exhibiting the increased consequences of resistance to antimicrobials. ${ }^{114}$ Therefore, an urgent need to provide alternatives to antibiotics has been determined.

For proposing alternatives to antimicrobials, the initial scope of antibiotic usage, namely, therapy, should be considered. Prevention in the form of an immunization program by vaccination could limit the amount of antibiotics needed. In contrast, the cost of vaccination is usually high, and the cross-protection against some pathogens is limited. ${ }^{115}$ Another way of preventing disease occurrence is the improvement of the gut bacterial flora by the use of probiotics, prebiotics, and synbiotics, as revised by Callaway et $\mathrm{al}^{116}$ and Gaggia et $\mathrm{al}^{117}$ The health of the gut microbial microecosystem contributes largely to the immune system functionality and nutrient use and provides less space for pathogen colonization. ${ }^{15,118}$ In poultry, a significant decrease in Salmonella colonization has been shown after administration of commensal anaerobic bacteria. The low number of the newly discovered Butyricicoccus pullicaecorum isolated from broiler cecum has been positively correlated with inflammatory bowel disease, with the disease reversed after oral administration of the bacterium. ${ }^{119}$ In addition, selected yeasts with appropriate properties or certain genetically modified strains could be used as probiotics. ${ }^{120}$ Although the improvement of the gut health seems promising, there is a need to access the effectiveness and the underlying mechanisms. ${ }^{119,121,122}$

The use of phages is quite intriguing, as they are characterized by specificity and selective neutralization of the pathogen of interest during the lytic phase of their life cycle. Furthermore, the use of phages is compatible with the use of other antimicrobials, as there is no influence between these treatments. Although promising, the use of phages has been limited to treatment of topical infections in humans, ${ }^{123}$ neutralization of foodborne pathogens in animals, ${ }^{124}$ and control of plant pathogens. ${ }^{125}$ Although they are considered more specific than antibiotics, they exhibit variable specificity, mainly influenced by the phage titer. Therefore, the effects of the phages on the microbiota, although expected to be lesser than those of the antibiotics, should be considered. ${ }^{115,126}$

Research on antimicrobial peptides is increasing, and the acquired knowledge is showing the way for future pharmaceutical applications. Antimicrobial peptides can be an alternative to traditional antibiotics, although some of these have been shown to have toxic effects on mammalian cells. One category of antimicrobial peptides lacking toxicity is the bacteriocins, which are ribosomally synthesized peptides. ${ }^{127}$ Certain bacteriocins have already been used as food preservatives. Nisin A, a bacteriocin produced by lactic acid bacteria, is currently used officially in more than 50 countries, with the US Food and Drug Administration proposing a daily uptake of up to $2.9 \mathrm{mg}$ per person per day. ${ }^{15,128}$ In general, they can be incorporated in a food product as an additive in the form of a purified compound, as a generally recognized as safe fermentate, or by adding the producer microbe as a starter culture. ${ }^{128}$ Still, bacteriocins in food production systems have been reported to reduce Listeria by only 1 or $2 \log ^{10} .^{129}$ Therefore, bacteriocins could be sufficient for pathogen destruction only if they form part of a hurdles system in which several low-efficiency antimicrobial treatments are used to produce a safe food product. ${ }^{128}$ In addition, the optimization of bacteriocin production, possibly through genetic engineering of the producing bacterium, could increase its efficacy. ${ }^{130}$ Although the application of bacteriocins involves mainly food products, they have been proposed for the control of zoonoses. ${ }^{131,132}$ Still, preceding their application, the bacteriocins should be examined for their in vivo stability, the appropriate delivery route, and possible toxicity issues. ${ }^{133}$

Another possible alternative to antimicrobials is the use of predatory bacteria. Bdellovibrio and associated 
organisms show potential in combating pathogenic bacteria in various niches, as they possess a full arsenal of DNases and proteases. ${ }^{115,134,135}$ Bdellovibrio and associated organisms show a nonspecific predation against Gramnegative bacteria. ${ }^{134}$ One of the main advantages of these predatory bacteria is that they can prey quite effectively even on bacterial biofilms. ${ }^{115,135}$ Bdellovibrio bacteriovorus and Micavibrio aeruginosavorus have been shown to prey on multidrug-resistant pathogens such as A. baumannii, E. coli, Klebsiella pneumoniae, Pseudomonas aeruginosa, and Pseudomonas putida, without being able to discriminate between antibiotic-resistant and antibiotic-susceptible strains. ${ }^{134}$ Another interesting factor of their biology is that they could serve both as antibiotic and probiotic organisms. The administration of $B$. bacteriovorus lowered the cecal carriage of $S$. enterica. ${ }^{136}$ In addition, they have been effectively used in treating ocular diseases such as the one caused by Shigella flexneri in rabbits and Moraxella bovis in cows. ${ }^{137}$ In contrast, there are some limitations concerning their possible application. Their predation on bacteria is not exhaustive, as a small number of bacteria remain. Although regarded as aerobic, or at least microaerophilic, ${ }^{138}$ they can destroy the natural flora of the body cavities. ${ }^{134}$ In addition, the predation in environments in which Gram-positive bacteria exist could lower the efficacy of predation. ${ }^{139}$ Therefore, it is evident that more research is needed toward the interac- tion among predatory bacteria, the host, and the commensal microbiota. ${ }^{115}$

\section{Measures to prevent emergence and transmission of antimicrobial- resistant bacteria}

The global situation concerning antibiotic resistance worldwide is at least alarming. In the present time, the recognition of the importance of antibiotic resistance is almost catholic. Therefore, certain measures have been implied by the states so as to mitigate this problem. In 2001, the World Health Organization has set the basis for the establishment of measures toward controlling antibiotic resistance. ${ }^{140}$ In summary, control measures should reduce the emergence and spread of antibiotic-resistant bacteria, improve use of antimicrobials, establish effective surveillance systems, enforce legislation, and encourage the development of new drugs and vaccines. More or less, these basic principles have been followed by both the European Union and the United States of America. The European Union, through the joint report by the European Centre for Disease Prevention and Control and the European Medicines Agency, has also expressed the urge for international cooperation so as to entrench antibiotic resistance. The White House has recently issued a national strategy plan for combating antibiotic resistance in which the goals issued have also added the necessity of

Table 3 Priority actions agreed in the Third World Healthcare Associated Infections Forum

\begin{tabular}{ll}
\hline Stakeholders & Priority actions \\
\hline $\begin{array}{l}\text { Policy makers and health } \\
\text { authorities }\end{array}$ & I. Animals. Stop the administration of antibiotics used in human medicine and limit antibiotics to \\
therapeutic use only. It is imperative to reserve the most important classes of antibiotics for humans. \\
2. Banish, in all countries, the use of antibiotics as growth promoters in animal feed. \\
3. Regulate the sale of antibiotics for use in human medicine and prohibit over-the-counter sales worldwide. \\
4. Have international organizations (World Health Organization, European Union) develop a charter \\
on good antibiotic stewardship and have all the ministries of health worldwide sign it and commit to \\
respecting it. \\
I. Establish standardized, universal surveillance of antibiotic use and resistance and monitor the \\
emergence and spread of new forms of bacterial resistance. \\
human and veterinary \\
$\begin{array}{l}\text { 2. Include, in medical and veterinary school curricula, a solid training in bacterial resistance and the } \\
\text { prudent use of antibiotics, and establish on-the-job training programs for health care workers, taking } \\
\text { into account the cultural specificities of each country. }\end{array}$ \\
$\begin{array}{ll}\text { I. Develop culturally sensitive awareness campaigns, targeted to the general public, explaining the } \\
\text { importance of protecting antibiotics and using them only when absolutely necessary. }\end{array}$ \\
$\begin{array}{l}\text { 2. Provide education about fundamental hygiene, such as handwashing, to prevent the spread of infection. } \\
\text { It is imperative to improve sanitation systems to eliminate resistant bacteria in wastewater. }\end{array}$ \\
$\begin{array}{l}\text { 3. Include consumers in the development and implementation of action plans. } \\
\text { I. Develop point-of-care and rapid diagnostic tests, which can be used at the patient's bedside or in the } \\
\text { Industry }\end{array}$ \\
$\begin{array}{l}\text { 2. Stimulate research and development of novel antibiotics. } \\
\text { 3. Find new economic models that reconcile public health interests with Industry needs for profitability. }\end{array}$
\end{tabular}

Note: Data from Jarlier V, Carlet J, McGowan J, et al; Participants of the 3rd World Healthcare-Associated Infections Forum. Priority actions to fight antibiotic resistance: results of an international meeting. Antimicrob Resist Infect Control. 2012; I (I):17.142 
international collaboration. ${ }^{141}$ Most interestingly, defined expected outcomes have been calculated in this national strategy plan. In both the European Union and the United States, the multidisciplinary collaboration is reported to be crucial, as summarized in the One Health initiative.

In 2011, more than 70 experts representing 33 countries have gathered in the Third World Healthcare Associated Infections Forum (WHAIF) which was dedicated to antibiotic resistance awareness and action. ${ }^{142}$ At the end of this forum, they have agreed on forming twelve actions by priority, which were also categorized according to the stakeholders that were addressed (Table 3). The stakeholders involved were the national and international health authorities and policy makers, the medical and veterinary communities, the general public, and industry. These messages are reported in Table 3. The results of the Third WHAIF have been received after 10 years from the World Health Organization and provide a revision of the World Health Organization principles. On the Fourth WHAIF, the priority actions agreed on during the Third WHAIF were reported as urgent after critical reconciliation of the findings reported by the participating experts. ${ }^{70}$

\section{Conclusion}

Antibiotic-resistant bacteria of animal origin are considered an important contributor to the overall phenomenon of resistance to antibiotics. Although the magnitude of their importance is still under debate, there are certain indications that show a direct link between resistance and antibiotic use in farm animals. However, this is not the issue: everyone who has used antibiotics has a share in the emergence of resistance, and because the situation is quite alarming, every effort should be made for the reversal of it. Judicious use of antibiotics in animals is a requirement to delay the emergence of bacteria resistant to the still-working antibiotics. The invention of novel drugs or the use of alternatives to antibiotics should also be encouraged. Still, the increased awareness of the scientific community and the stakeholders in general is both alarming and promising at the same time. The planning of future strategies has already taken place, and in general, it has been agreed on. Therefore, a combined international action is needed toward the solution of this problem.

\section{Disclosure}

The authors report no conflicts of interest in this work.

\section{References}

1. Angulo FJ, Baker NL, Olsen SJ, Anderson A, Barrett TJ. Antimicrobial use in agriculture: controlling the transfer of antimicrobial resistance to humans. Semin Pediatr Infect Dis. 2004;15(2):78-85.
2. Silbergeld EK, Graham J, Price LB. Industrial food animal production, antimicrobial resistance, and human health. Annu Rev Public Health. 2008;29(1):151-169.

3. World Health Association. The Medical Impact of the Use of Antimicrobials in Food Animals. World Health Organization; 1997. Available from: http://whqlibdoc.who.int/hq/1997/WHO_EMC_ZOO_97.4.pdf. Accessed December 15, 2014.

4. Davies J, Davies D. Origins and evolution of antibiotic resistance. Microbiol Mol Biol Rev. 2010;74(3):417-433.

5. World Health Organization. Antimicrobial Resistance. Fact Sheet 194. World Health Organization; 2014. Available from: http://www.who.int/ mediacentre/factsheets/fs194/en/. Accessed December 15, 2014.

6. US Food and Drug Adminstration. Guidance for Industry \#209: The Judicious Use of Medically Important Antimicrobial Drugs in FoodProducing Animals. US Food and Drug Administration; 2012. Available from: http://www.fda.gov/downloads/AnimalVeterinary/GuidanceComplianceEnforcement/GuidanceforIndustry/UCM216936.pdf. Accessed December 15, 2014.

7. Barber M, Rozwadowska-Dowzenko M. Infection by penicillin-resistant staphylococci. Lancet. 1948;2(6530):641-644.

8. Crofton J, Mitchison DA. Streptomycin resistance in pulmonary tuberculosis. BMJ. 1948;2(4588):1009-1015.

9. Watanabe $\mathrm{T}$. Infective heredity of multiple drug resistance in bacteria. Bacteriol Rev. 1963;27:87-115.

10. Olarte J. Antibiotic resistance in Mexico. APUA Newslett. 1983;1:3.

11. Cantas L, Shah SQA, Cavaco LM, et al. A brief multi-disciplinary review on antimicrobial resistance in medicine and its linkage to the global environmental microbiota. Front Microbiol. 2013;4:96.

12. Levy SB, Marshall B. Antibacterial resistance worldwide: causes, challenges and responses. Nat Med. 2004;10(12)(Suppl):S122-S129.

13. Marshall BM, Levy SB. Food animals and antimicrobials: impacts on human health. Clin Microbiol Rev. 2011;24(4):718-733.

14. Watts J, Lindeman C. Antimicrobial susceptibility testing of bacteria of veterinary origin. In: Aarestrup FM, editor. Antimicrobial Resistance in Bacteria of Animal Origin. Washington, DC: ASM Press; 2006:29-35.

15. US Food and Drug Administration Center for Veterinary Medicine. Judicious Use of Antimicrobials for Beef Cattle Veterinarians. US Food and Drug Administration Center for Veterinary Medicine. Available from: http://www.fda.gov/downloads/AnimalVeterinary/SafetyHealth/ AntimicrobialResistance/JudiciousUseofAntimicrobials/UCM095568. pdf. Accessed December 10, 2014.

16. Compassion in World Farming. Antibiotics in Farm Animal Production. Public Health and Animal Welfare. Compassion in World Farming; 2011. Available from: http://www.fao.org/fileadmin/user_upload/animalwelfare/ antibiotics_in_animal_farming.pdf. Accessed December 15, 2014.

17. Stokstad ELR, Jukes TH. Further observations on the "animal protein factor." Proc Soc Exp Biol Med. 1950;73(3):523-528.

18. Giguère $\mathrm{S}$. Antimicrobial drug action and interaction. In: Giguère $\mathrm{S}$, Prescott JF, Dowling PM, editors. Antimicrobial Therapy in Veterinary Medicine. 5th ed. Ames (IA): Blackwell Publishing; 2013:1-10.

19. Alexander TW, Yanke LJ, Topp E, et al. Effect of subtherapeutic administration of antibiotics on the prevalence of antibiotic-resistant Escherichia coli bacteria in feedlot cattle. Appl Environ Microbiol. 2008;74(14):4405-4416.

20. US Food and Drug Association. Judicious Use Brochures. US Food and Drug Association. Available from: http://www.fda.gov/AnimalVeterinary/ SafetyHealth/AntimicrobialResistance/JudiciousUseofAntimicrobials/ ucm378095.htm. Accessed December 15, 2014.

21. Hunter PA, Dawson S, French GL, et al. Antimicrobial-resistant pathogens in animals and man: prescribing, practices and policies. J Antimicrob Chemother. 2010;65(Suppl 1):i3-i17.

22. European Medicines Agency. Trends in the Sales of Veterinary Antimicrobial Agents in Nine European Countries (2005-2009). European Medicines Agency; 2011. Available from: http://www.ema.europa.eu/ docs/en_GB/document_library/Report/2011/09/WC500112309.pdf. Accessed December 15, 2014. 
23. European Medicines Agency. Sales of Veterinary Antimicrobial Agents in 25 EU/EEA Countries in 2011. European Medicines Agency; 2013. Available from: http://www.ema.europa.eu/docs/en_GB/document_library/ Report/2013/10/WC500152311.pdf. Accessed December 15, 2014.

24. European Medicines Agency. Sales of Veterinary Antimicrobial Agents in 26 EU/EEA Countries in 2012. European Medicines Agency; 2014. Available from: http://www.ema.europa.eu/docs/en_GB/document_library/ Report/2014/10/WC500175671.pdf. Accessed December 15, 2014.

25. FDA Center for Veterinary Medicine. 2009 Summary Report on Antimicrobials Sold or Distributed for Use in Food-Producing Animals. US Food and Drug Administration; 2014. Available from: http://www.fda. gov/downloads/ForIndustry/UserFees/AnimalDrugUserFeeActADUFA/ UCM231851.pdf. Accessed December 15, 2014.

26. FDA Center for Veterinary Medicine. 2010 Summary Report on Antimicrobials Sold or Distributed for Use in Food-Producing Animals. US Food and Drug Administration; 2014. Available from: http://www.fda. gov/downloads/ForIndustry/UserFees/AnimalDrugUserFeeActADUFA/ UCM277657.pdf. Accessed December 15, 2014.

27. FDA Center for Veterinary Medicine. 2011 Summary Report on Antimicrobials Sold or Distributed for Use in Food-Producing Animals. US Food and Drug Administration; 2014. Available from: http://www.fda. gov/downloads/ForIndustry/UserFees/AnimalDrugUserFeeActADUFA/ UCM338170.pdf. Accessed December 15, 2014.

28. FDA Center for Veterinary Medicine. 2012 Summary Report on Antimicrobials Sold or Distributed for Use in Food-Producing Animals. US Food and Drug Administration; 2014. Available from: http://www.fda. gov/downloads/ForIndustry/UserFees/AnimalDrugUserFeeActADUFA/ UCM416983.pdf. Accessed December 15, 2014.

29. McEwen SA, Fedorka-Cray PJ. Antimicrobial use and resistance in animals. Clin Infect Dis. 2002;34(s3)(Suppl 3):S93-S106.

30. Constable P, Pyorala S, Smith GW. Guidelines for antimicrobial use in cattle. In: Guardabassi L, Jensen LB, Kruse H, editors. Guide to Antimicrobial Use in Animals. Ames (IA): Blackwell Publishing Ltd; 2008:1-222.

31. US Department of Agriculture. Part III: Health Management and Biosecurity in US Feedlots, 1999. US Department of Agriculture; 2000. Available from: http://www.aphis.usda.gov/animal_health/nahms/ feedlot/downloads/feedlot99/Feedlot99_dr_PartIII.pdf. Accessed December 15, 2014.

32. Wagner $\mathrm{S}$, Erskine R. Antimicrobial drug use in mastitis. In: Giguère S, Prescott JF, Dowling PM, editors. Antimicrobial Therapy in Veterinary Medicine. 5th ed. Ames (IA): Blackwell Publishing; 2013:519-528.

33. US Department of Agriculture. Cattle and Calves Nonpredator Death Loss in the United States, 2010. US Department of Agriculture; 2011. Available from: http://www.aphis.usda.gov/animal_health/nahms/ general/downloads/cattle_calves_nonpred_2010.pdf. Accessed December 15, 2014.

34. Burch DGS. Antimicrobial drug use in swine. In: Giguère S, Prescott JF, Dowling PM, editors. Antimicrobial Therapy in Veterinary Medicine. 5th ed. Ames (IA): Blackwell Publishing; 2013:553-568.

35. Dewey CE, Cox BD, Straw BE, et al. Use of antimicrobials in swine feeds in the United States. Swine Health Prod. 1999;7(1):19-25.

36. Dunlop RH, McEwen SA, Meek AH, Friendship RA, Clarke RC, Black WD. Antimicrobial drug use and related management practices among Ontario swine producers. Can Vet J. 1998;39(2):87-96.

37. Hofacre CL, Fricke JA, Inglis T. Antimicrobial drug use in poultry. In: Giguère S, Prescott JF, Dowling PM, editors. Antimicrobial Therapy in Veterinary Medicine. 5th ed. Ames (IA): Blackwell Publishing; 2013:569-587.

38. Clark CR. Antimicrobial drug use in sheep and goats. In: Giguère S, Prescott JF, Dowling PM, editors. Antimicrobial Therapy in Veterinary Medicine. 5th ed. Ames (IA): Blackwell Publishing; 2013:529-539.

39. Cabello FC. Heavy use of prophylactic antibiotics in aquaculture: a growing problem for human and animal health and for the environment. Environ Microbiol. 2006;8(7):1137-1144.
40. Heuer OE, Kruse H, Grave K, Collignon P, Karunasagar I, Angulo FJ. Human health consequences of use of antimicrobial agents in aquaculture. Clin Infect Dis. 2009;49(8):1248-1253.

41. World Health Organization. Tackling Antibiotic Resistance from a Food Safety Perspective in Europe. Copenhagen: World Health Organization; 2011. Available from: http://www.euro.who.int/_data/assets/ pdf_file/0005/136454/e94889.pdf. Accessed December 15, 2014.

42. Miranda CD, Tello A, Keen PL. Mechanisms of antimicrobial resistance in finfish aquaculture environments. Front Microbiol. 2013;4: 233-237.

43. Schwarz S, Kehrenberg C, Doublet B, Cloeckaert A. Molecular basis of bacterial resistance to chloramphenicol and florfenicol. FEMS Microbiol Rev. 2004;28(5):519-542.

44. Roberts MC. Update on acquired tetracycline resistance genes. FEMS Microbiol Lett. 2005;245(2):195-203.

45. Koluman A, Dikici A. Antimicrobial resistance of emerging foodborne pathogens: status quo and global trends. Crit Rev Microbiol. 2013; 39(1):57-69.

46. Padungton P, Kaneene JB. Campylobacter spp in human, chickens, pigs and their antimicrobial resistance. J Vet Med Sci. 2003;65(2):161-170.

47. Alfredson DA, Korolik V. Antibiotic resistance and resistance mechanisms in Campylobacter jejuni and Campylobacter coli. FEMS Microbiol Lett. 2007;277(2):123-132.

48. Engberg J, Keelan M, Gerner-Smidt P, Taylor D. Antimicrobial resistance in Campylobacter. In: Aaerstrup FM, editor. Antimicrobial Resistance in Bacteria of Animal Origin. Washington: ASM Press; 2006: 269-291.

49. Endtz HP, Ruijs GJ, van Klingeren B, Jansen WH, van der Reyden T, Mouton RP. Quinolone resistance in campylobacter isolated from man and poultry following the introduction of fluoroquinolones in veterinary medicine. J Antimicrob Chemother. 1991;27(2):199-208.

50. Blaser MJ. Campylobacter jejuni and related species. In: Bennett JE, Dolin R, editors. Principles and Practice of Infectious Diseases. New York: Churchill Livingstone Inc.; 2000:2276-2285.

51. Gibreel A, Tracz DM, Nonaka L, Ngo TM, Connell SR, Taylor DE. Incidence of antibiotic resistance in Campylobacter jejuniisolated in Alberta, Canada, from 1999 to 2002, with special reference to tet(O)mediated tetracycline resistance. Antimicrob Agents Chemother. 2004; 48(9):3442-3450.

52. Gaudreau C, Gilbert H. Antimicrobial resistance of Campylobacter jejuni subsp. jejuni strains isolated from humans in 1998 to 2001 in Montréal, Canada. Antimicrob Agents Chemother. 2003;47(6): 2027-2029.

53. Tuz-Dzib F, Guerrero ML, Cervantes LE, Pickering LK, RuizPalacios GM. Increased incidence of quinolone resistance among clinical isolates of Campylobacter jejuni in Mexico. Abstracts of the 10th International Workshop on Campylobacter, Helicobacter and Related Organisms. September 12-16, 1999, Baltimore, MD, USA.

54. Gupta A, Nelson JM, Barrett TJ, et al; NARMS Working Group. Antimicrobial resistance among Campylobacter strains, United States, 1997-2001. Emerg Infect Dis. 2004;10(6):1102-1109.

55. Luber P, Wagner J, Hahn H, Bartelt E. Antimicrobial resistance in Campylobacter jejuni and Campylobacter coli strains isolated in 1991 and 2001-2002 from poultry and humans in Berlin, Germany. Antimicrob Agents Chemother. 2003;47(12):3825-3830.

56. EFSA (European Food Safety Authority) and ECDC (European Centre for Disease Prevention and Control). The European Union Summary Report on antimicrobial resistance in zoonotic and indicator bacteria from humans, animals and food in 2012. EFSA Journal. 2014;12(3):3590.

57. Centers for Disease Control and Prevention, US Department of Agriculture, US Food and Drug Administration. National Antimicrobial Resistance Monitoring System 2011 Executive Report. Available from: http://www.fda.gov/downloads/AnimalVeterinary/SafetyHealth/ AntimicrobialResistance/NationalAntimicrobialResistanceMonitoring System/UCM407962.pdf. Accessed December 15, 2014.

58. Holmberg SD, Wells JG, Cohen ML. Animal-to-man transmission of antimicrobial-resistant Salmonella: investigations of US outbreaks, 1971-1983. Science. 1984;225(4664):833-835. 
59. Spika JS, Waterman SH, Hoo GWS, et al. Chloramphenicol-resistant Salmonella newport traced through hamburger to dairy farms. A major persisting source of human salmonellosis in California. N Engl J Med. 1987;316(10):565-570.

60. Olsen SJ, Ying M, Davis MF, et al. Multidrug-resistant Salmonella Typhimurium infection from milk contaminated after pasteurization. Emerg Infect Dis. 2004;10(5):932-935.

61. Gebreyes WA, Altier C. Molecular characterization of multidrugresistant Salmonella enterica subsp. enterica serovar Typhimurium isolates from swine. J Clin Microbiol. 2002;40(8):2813-2822.

62. Alcaine SD, Warnick LD, Wiedmann M. Antimicrobial resistance in nontyphoidal Salmonella. J Food Prot. 2007;70(3):780-790.

63. Foley SL, Lynne AM. Food animal-associated Salmonella challenges: pathogenicity and antimicrobial resistance. J Anim Sci. 2008 86(14)(Suppl):E173-E187.

64. Rabsch W, Tschäpe H, Bäumler AJ. Non-typhoidal salmonellosis: emerging problems. Microbes Infect. 2001;3(3):237-247.

65. Hanson ND, Moland ES, Hossain A, Neville SA, Gosbell IB, Thomson KS. Unusual Salmonella enterica serotype Typhimurium isolate producing CMY-7, SHV-9 and OXA-30 $\beta$-lactamases. J Antimicrob Chemother. 2002;49(6):1011-1014.

66. Baggesen DL, Sandvang D, Aarestrup FM. Characterization of Salmonella enterica serovar typhimurium DT104 isolated from Denmark and comparison with isolates from Europe and the United States. J Clin Microbiol. 2000;38(4):1581-1586.

67. Davis MA, Hancock DD, Besser TE. Multiresistant clones of Salmonella enterica: the importance of dissemination. J Lab Clin Med. 2002;140(3):135-141.

68. McDermott P. Antimicrobial resistance in nontyphoidal Salmonellae. In: Aaerstrup FM, editor. Antimicrobial Resistance in Bacteria of Animal Origin. Washington: ASM Press; 2006:293-314.

69. Aarestrup FM, Schwarz S. Antimicrobial Resistance in Staphylococci and Streptococci of animal origin. In: Aarestrup FM, editor Antimicrobial Resistance in Bacteria of Animal Origin. Washington, DC: ASM Press; 2006:187-212.

70. Huttner A, Harbarth S, Carlet J, et al. Antimicrobial resistance: a global view from the 2013 World Healthcare-Associated Infections Forum. Antimicrob Resist Infect Control. 2013;2:31.

71. Gousia P, Economou V, Sakkas H, Leveidiotou S, Papadopoulou C. Antimicrobial resistance of major foodborne pathogens from major meat products. Foodborne Pathog Dis. 2011;8(1):27-38.

72. Frey Y, Rodriguez JP, Thomann A, Schwendener S, Perreten V. Genetic characterization of antimicrobial resistance in coagulase-negative staphylococci from bovine mastitis milk. J Dairy Sci. 2013;96(4): 2247-2257.

73. Cuny C, Friedrich A, Kozytska S, et al. Emergence of methicillinresistant Staphylococcus aureus (MRSA) in different animal species. Int J Med Microbiol. 2010;300(2-3):109-117.

74. Oppliger A, Moreillon P, Charrière N, Giddey M, Morisset D, Sakwinska O. Antimicrobial resistance of Staphylococcus aureus strains acquired by pig farmers from pigs. Appl Environ Microbiol. 2012;78(22):8010-8014.

75. Murray BE. The life and times of the Enterococcus. Clin Microbiol Rev. 1990;3(1):46-65.

76. Hummel A, Holzapfel WH, Franz CMAP. Characterisation and transfer of antibiotic resistance genes from enterococci isolated from food. Syst Appl Microbiol. 2007;30(1):1-7.

77. Werner G, Coque TM, Franz CM, et al. Antibiotic resistant enterococcitales of a drug resistance gene trafficker. Int J Med Microbiol. 2013; 303(6-7):360-379.

78. Tacconelli E, Cataldo MA. Vancomycin-resistant enterococci (VRE): transmission and control. Int J Antimicrob Agents. 2008;31(2): 99-106.

79. Staley C, Dunny GM, Sadowsky MJ. Chapter Four - Environmental and animal-associated enterococci. In: Sariaslani S, Gadd GM, editors. Advances in Applied Microbiology. Vol 87. San Diego: Academic Press; 2014:147-186.
80. Hayes JR, English LL, Carter PJ, et al. Prevalence and antimicrobial resistance of enterococcus species isolated from retail meats. Appl Environ Microbiol. 2003;69(12):7153-7160.

81. Gousia P, Economou V, Bozidis P, Papadopoulou C. Vancomycin resistance phenotypes, vancomycin resistance genes, and resistance to antibiotics of enterococci isolated from food of animal origin. Foodborne Pathog Dis. Epub January 6, 2015.

82. Mayhall CG. Prevention and control of vancomycin resistance in grampositive coccal microorganisms: fire prevention and fire fighting. Infect Control Hosp Epidemiol. 1996;17(6):353-355.

83. Harada T, Kawahara R, Kanki M, Taguchi M, Kumeda Y. Isolation and characterization of vanA genotype vancomycin-resistant Enterococcus cecorum from retail poultry in Japan. Int J Food Microbiol. 2012;153(3):372-377

84. Oteo J, Pérez-Vázquez M, Campos J. Extended-spectrum [beta]lactamase producing Escherichia coli: changing epidemiology and clinical impact. Curr Opin Infect Dis. 2010;23(4):320-326.

85. Simner PJ, Zhanel GG, Pitout J, et al; Canadian Antimicrobial Resistance Alliance (CARA). Prevalence and characterization of extendedspectrum $\beta$-lactamase- and AmpC $\beta$-lactamase-producing Escherichia coli: results of the CANWARD 2007-2009 study. Diagn Microbiol Infect Dis. 2011;69(3):326-334.

86. Pathak A, Marothi Y, Kekre V, Mahadik K, Macaden R, Lundborg CS. High prevalence of extended-spectrum $\beta$-lactamase-producing pathogens: results of a surveillance study in two hospitals in Ujjain, India. Infect Drug Resist. 2012;5:65-73.

87. Reich F, Atanassova V, Klein G. Extended-spectrum $\beta$-lactamase- and AmpC-producing enterobacteria in healthy broiler chickens, Germany. Emerg Infect Dis. 2013;19(8):1253-1259.

88. Colpan A, Johnston B, Porter S, et al; VICTORY (Veterans Influence of Clonal Types on Resistance: Year 2011) Investigators. Escherichia coli sequence type 131 (ST131) subclone H30 as an emergent multidrug-resistant pathogen among US veterans. Clin Infect Dis. 2013;57(9):1256-1265.

89. Overdevest I, Willemsen I, Rijnsburger M, et al. Extended-spectrum $\beta$-lactamase genes of Escherichia coli in chicken meat and humans, The Netherlands. Emerg Infect Dis. 2011;17(7):1216-1222.

90. Kluytmans JAK, Overdevest IT, Willemsen I, et al. Extended-spectrum $\beta$-lactamase-producing Escherichia coli from retail chicken meat and humans: comparison of strains, plasmids, resistance genes, and virulence factors. Clin Infect Dis. 2013;56(4):478-487.

91. Soonthornchaikul N, Garelick H. Antimicrobial resistance of Campylobacter species isolated from edible bivalve molluscs purchased from Bangkok markets, Thailand. Foodborne Pathog Dis. 2009;6(8):947-951.

92. Levy SB, FitzGerald GB, Macone AB. Changes in intestinal flora of farm personnel after introduction of a tetracycline-supplemented feed on a farm. N Engl J Med. 1976;295(11):583-588.

93. Petersen A, Andersen JS, Kaewmak T, Somsiri T, Dalsgaard A. Impact of integrated fish farming on antimicrobial resistance in a pond environment. Appl Environ Microbiol. 2002;68(12):6036-6042.

94. Shah SQA, Colquhoun DJ, Nikuli HL, Sørum H. Prevalence of antibiotic resistance genes in the bacterial flora of integrated fish farming environments of Pakistan and Tanzania. Environ Sci Technol. 2012;46(16):8672-8679.

95. Riesenfeld CS, Schloss PD, Handelsman J. Metagenomics: genomic analysis of microbial communities. Annu Rev Genet. 2004;38(1): 525-552.

96. D'Costa VM, McGrann KM, Hughes DW, Wright GD. Sampling the antibiotic resistome. Science. 2006;311(5759):374-377.

97. Rossi F, Rizzotti L, Felis GE, Torriani S. Horizontal gene transfer among microorganisms in food: current knowledge and future perspectives. Food Microbiol. 2014;42:232-243.

98. Toomey N, Monaghan A, Fanning S, Bolton DJ. Assessment of antimicrobial resistance transfer between lactic acid bacteria and potential foodborne pathogens using in vitro methods and mating in a food matrix. Foodborne Pathog Dis. 2009;6(8):925-933. 
99. Doucet-Populaire F, Trieu-Cuot P, Dosbaa I, Andremont A, Courvalin P. Inducible transfer of conjugative transposon Tn1545 from Enterococcus faecalis to Listeria monocytogenes in the digestive tracts of gnotobiotic mice. Antimicrob Agents Chemother. 1991;35(1):185-187.

100. Walsh C, Duffy G, Nally P,O’Mahony R, McDowell DA, Fanning S. Transfer of ampicillin resistance from Salmonella Typhimurium DT104 to Escherichia coli K12 in food. Lett Appl Microbiol. 2008;46(2):210-215.

101. Rizzotti L, La Gioia F, Dellaglio F, Torriani S. Molecular diversity and transferability of the tetracycline resistance gene tet(M), carried on Tn916-1545 family transposons, in enterococci from a total food chain. Antonie van Leeuwenhoek. 2009;96(1):43-52.

102. Smet A, Rasschaert G, Martel A, et al. In situ ESBL conjugation from avian to human Escherichia coli during cefotaxime administration. J Appl Microbiol. 2011;110(2):541-549.

103. Leverstein-van Hall MA, Dierikx CM, Cohen Stuart J, et al; National ESBL surveillance group. Dutch patients, retail chicken meat and poultry share the same ESBL genes, plasmids and strains. Clin Microbiol Infect. 2011;17(6):873-880.

104. Doyle MP, Erickson MC. Emerging microbiological food safety issues related to meat. Meat Sci. 2006;74(1):98-112.

105. Fluit AC. Towards more virulent and antibiotic-resistant Salmonella? FEMS Immunol Med Microbiol. 2005;43(1):1-11.

106. Guerra B, Junker E, Miko A, Helmuth R, Mendoza MC. Characterization and localization of drug resistance determinants in multidrug-resistant, integron-carrying Salmonella enterica serotype Typhimurium strains. Microb Drug Resist. 2004;10(2):83-91.

107. Gooderham WJ, Hancock REW. Regulation of virulence and antibiotic resistance by two-component regulatory systems in Pseudomonas aeruginosa. FEMS Microbiol Rev. 2009;33(2):279-294.

108. Oliver SP, Murinda SE, Jayarao BM. Impact of antibiotic use in adult dairy cows on antimicrobial resistance of veterinary and human pathogens: a comprehensive review. Foodborne Pathog Dis. 2011;8(3):337-355.

109. Capita R, Alonso-Calleja C. Antibiotic-resistant bacteria: a challenge for the food industry. Crit Rev Food Sci Nutr. 2013;53(1):11-48.

110. Angulo FJ, Nunnery JA, Bair HD. Antimicrobial resistance in zoonotic enteric pathogens. Rev Sci Tech. 2004;23(2):485-496.

111. Verraes C, Van Boxstael S, Van Meervenne E, et al. Antimicrobial resistance in the food chain: a review. Int J Environ Res Public Health. 2013;10(7):2643-2669.

112. European Centre for Disease Prevention and Control, European Medicines Agency. The Bacterial Challenge: Time to React. A Call to Narrow the Gap Between Multidrug-Resistant Bacteria in the EU and the Development of New Antibacterial Agents. European Centre for Disease Prevention and Control; 2009. Available from: http:// www.ecdc.europa.eu/en/publications/Publications/0909_TER_The_ Bacterial_Challenge_Time_to_React.pdf. Accessed December 15, 2014.

113. Jassim SA, Limoges RG. Natural solution to antibiotic resistance: bacteriophages 'The Living Drugs'. World J Microbiol Biotechnol. 2014;30(8):2153-2170.

114. US Congress. HR 965 (112th). Preservation of Antibiotics for Medical Treatment Act of 2011. Available from: https://www.govtrack.us/ congress/bills/112/hr965. Accessed December 15, 2014.

115. Allen HK, Trachsel J, Looft T, Casey TA. Finding alternatives to antibiotics. Ann N Y Acad Sci. 2014;1323(1):91-100.

116. Callaway TR, Edrington TS, Anderson RC, et al. Probiotics, prebiotics and competitive exclusion for prophylaxis against bacterial disease. Anim Health Res Rev. 2008;9(2):217-225.

117. Gaggìa F, Mattarelli P, Biavati B. Probiotics and prebiotics in animal feeding for safe food production. Int J Food Microbiol. 2010; 141(Suppl 1):S15-S28.

118. Zoetendal EG, Cheng B, Koike S, Mackie RI. Molecular microbial ecology of the gastrointestinal tract: from phylogeny to function. $\mathrm{Curr}$ Issues Intest Microbiol. 2004;5(2):31-47.

119. Seal BS, Lillehoj HS, Donovan DM, Gay CG. Alternatives to antibiotics: a symposium on the challenges and solutions for animal production. Anim Health Res Rev. 2013;14(1):78-87.
120. Biliouris K, Babson D, Schmidt-Dannert C, Kaznessis YN. Stochastic simulations of a synthetic bacteria-yeast ecosystem. BMC Syst Biol. 2012;6(1):58.

121. Kenny M, Smidt H, Mengheri E, Miller B. Probiotics - do they have a role in the pig industry? Animal. 2011;5(3):462-470.

122. Huyghebaert G, Ducatelle R, Van Immerseel F. An update on alternatives to antimicrobial growth promoters for broilers. Vet J. 2011;187(2): 182-188.

123. Chan BK, Abedon ST, Loc-Carrillo C. Phage cocktails and the future of phage therapy. Future Microbiol. 2013;8(6):769-783.

124. Goodridge LD, Bisha B. Phage-based biocontrol strategies to reduce foodborne pathogens in foods. Bacteriophage. 2011;1(3):130-137.

125. Balogh B, Jones JB, Iriarte FB, Momol MT. Phage therapy for plant disease control. Curr Pharm Biotechnol. 2010;11(1):48-57.

126. Koskella B, Meaden S. Understanding bacteriophage specificity in natural microbial communities. Viruses. 2013;5(3):806-823.

127. Papagianni M, Anastasiadou S. Pediocins: the bacteriocins of Pediococci. Sources, production, properties and applications. Microb Cell Fact. 2009;8(1):3.

128. Snyder AB, Worobo RW. Chemical and genetic characterization of bacteriocins: antimicrobial peptides for food safety. J Sci Food Agric. 2014;94(1):28-44.

129. Lou Y, Yousef AE. Adaptation to sublethal environmental stresses protects Listeria monocytogenes against lethal preservation factors. Appl Environ Microbiol. 1997;63(4):1252-1255.

130. GálvezA, Abriouel H, López RL, Ben Omar N. Bacteriocin-based strategies for food biopreservation. Int J Food Microbiol. 2007; 120(1-2):51-70.

131. Stern NJ, Eruslanov BV, Pokhilenko VD, et al. Bacteriocins reduce Campylobacter jejuni colonization while bacteria producing bacteriocins are ineffective. Microb Ecol Health Dis. 2008;20(2): 74-79.

132. Stern NJ, Svetoch EA, Eruslanov BV, et al. Paenibacillus polymyxa purified bacteriocin to control Campylobacter jejuni in chickens. J Food Prot. 2005;68(7):1450-1453.

133. Hammami R, Fernandez B, Lacroix C, Fliss I. Anti-infective properties of bacteriocins: an update. Cell Mol Life Sci. 2013;70(16): 2947-2967.

134. Kadouri DE, To K, Shanks RM, Doi Y. Predatory bacteria: a potential ally against multidrug-resistant Gram-negative pathogens. PLOS ONE. 2013;8(5):e63397.

135. Lambert C, Sockett RE. Nucleases in Bdellovibrio bacteriovorus contribute towards efficient self-biofilm formation and eradication of preformed prey biofilms. FEMS Microbiol Lett. 2013;340(2):109-116.

136. Atterbury RJ, Hobley L, Till R, et al. Effects of orally administered Bdellovibrio bacteriovorus on the well-being and Salmonella colonization of young chicks. Appl Environ Microbiol. 2011;77(16): 5794-5803.

137. Dwidar M, Monnappa AK, Mitchell RJ. The dual probiotic and antibiotic nature of Bdellovibrio bacteriovorus. BMB Rep. 2012;45(2): 71-78.

138. Schoeffield AJ, Williams HN, Turng B, Fackler WA Jr. A comparison of the survival of intraperiplasmic and attack phase Bdellovibrios with reduced oxygen. Microb Ecol. 1996;32(1):35-46.

139. Hobley L, King JR, Sockett RE. Bdellovibrio predation in the presence of decoys: three-way bacterial interactions revealed by mathematical and experimental analyses. Appl Environ Microbiol. 2006;72(10):6757-6765.

140. World Health Organization. WHO Global Strategy for Containment of Antimicrobial Resistance. World Health Organization; 2001. Available at: http://www.who.int/drugresistance/WHO_Global_Strategy_ English.pdf. Accessed December 15, 2014.

141. The President's Council of Advisors on Science and Technology. Report to the President on combating Antibiotic Resistance. Available at: http://www.whitehouse.gov/sites/default/files/microsites/ostp/PCAST/ pcast_carb_report_sept2014.pdf. Accessed December 15, 2014.

142. Jarlier V, Carlet J, McGowan J, et al; Participants of the 3rd World Healthcare-Associated Infections Forum. Priority actions to fight antibiotic resistance: results of an international meeting. Antimicrob Resist Infect Control. 2012;1(1):17. 
Infection and Drug Resistance

\section{Publish your work in this journal}

Infection and Drug Resistance is an international, peer-reviewed openaccess journal that focuses on the optimal treatment of infection (bacterial, fungal and viral) and the development and institution of preventive strategies to minimize the development and spread of resistance. The journal is specifically concerned with the epidemiology of antibiotic

resistance and the mechanisms of resistance development and diffusion in both hospitals and the community. The manuscript management system is completely online and includes a very quick and fair peerreview system, which is all easy to use. Visit http://www.dovepress.com/ testimonials.php to read real quotes from published authors.

Submit your manuscript here: http://www.dovepress.com/infection-and-drug-resistance-journal 